\title{
Regional Feeding Patterns of the Longnose Lancetfish (Alepisaurus ferox Lowe, 1833) of the Western Indian Ocean
}

\author{
Evgeny V. Romanov ${ }^{1}$ and Veniamin V. Zamorov ${ }^{2}$ \\ ${ }^{I} I R D$, UR 109 THETIS, Centre de Recherche Halieutique Méditerranéenne et Tropicale Avenue Jean Monnet- \\ BP 171, 34203 Sète Cedex, France; ${ }^{2}$ I. I. Mechnikov Odessa National University (ONU). 2, Dvoryanskaya St., \\ 65000, Odessa, Ukraine
}

\begin{abstract}
Key words: Indian Ocean, lancetfish, predation, pelagic environment, food composition, biogeographic provinces

Abstract-The food composition of the longnose lancetfish (Alepisaurus ferox Lowe, 1833) was studied in two areas belonging to different biogeographic provinces of the western Indian Ocean: Indian Monsoon Gyres Province (MONS) and Indian South Subtropical Gyre Province (ISSG). A total of 158 lancetfish were sampled during two research longline cruises in 1986-1987: 50 within the MONS, from the western equatorial area (between the EEZs of Kenya and Seychelles) and 108 within the ISSG, from the northern part of the EEZ of Mauritius (Saya-de-Malha Bank - Agalega Islands area). In the equatorial area, 135 prey items (of 18 families or higher taxa) were found in the lancetfish stomachs. In the waters of Mauritius, 476 prey items of 53 taxa were recorded. Regional variability in the feeding habits reflects province-specific differences in the prey abundance and the structure of pelagic communities of the intermediate trophic levels. Large predatory crustaceans dominate in the waters of MONS, while they are absent in the poor waters of ISSG. Foraging success of the lancetfish on non-evasive prey was 3.2 times higher in the MONS than in the ISSG. In overall, swimming crab, Hyperiidea, conspecifics, barracudina, hatchetfish, hammerjaw, and Polychaeta were the predominant prey of the lancetfish. Great differences in the food composition of 'small' ( $\mathrm{FL}<100 \mathrm{~cm}$ ) and 'large' ( $\mathrm{FL} \geq 100 \mathrm{~cm}$ ) lancetfish were recorded. For large lancetfish, the cannibalism rate and the occurrence of large evasive prey and Sargassum algae floating at the sea surface were greater than for small lancetfish.
\end{abstract}

\section{INTRODUCTION}

The longnose lancetfish (Alepisaurus ferox Lowe, 1833 ) is widely distributed in the pelagic zone of all the tropical oceans. This species is common in the bycatch of tuna longline fisheries (Silas, 1965, 1969; Ward et al., 2004). It is considered as an opportunistic predator that forages on all available prey, including conspecifics of smaller sizes (Parin, 1968, 1988).

Lancetfish are often the prey of yellowfin and bigeye tunas (Fourmanoir, 1971; Borodulina, 1974, 1981; Kornilova, 1979, 1980), which are the principal commercial species and the most abundant top predators in the tropical pelagic zone. Potential food competition may also exist between tunas and lancetfish since many organisms of the macrozooplankton and micronekton are commonly consumed by these species (Parin et al., 1969; Grandperrin \& Legand, 1970; Matthews et al., 1977; Parin, 1988; Tsuchiya et al., 1998).

Further studies of the food composition of lancetfish can expand the present knowledge about the biology of these fishes, which remains poorly known. Due to its abundance, opportunistic nature of predation and very low state of digestion of the prey found in its stomach (Rofen, 1966), lancetfish may be used as a biological sampler, which collects 
well preserved specimens of the forage organisms. Therefore such studies will provide information about the role of these predators in the trophic webs of the oceanic pelagic zone as well as data on species composition and abundance of prey organisms of lancetfish and other top predators in the tropical waters. This is important for further development of an ecosystem approach to fisheries management in the high seas (FAO, 1995, 2003).

Feeding habits and overall diet of lancetfish were relatively well-studied in the Pacific (Haedrich \& Nielsen, 1966; Fourmanoir, 1969; Grandperrin \& Legand, 1970; Kubota \& Uyeno, 1970; Rancurel, 1970; Moteki et al., 1993) and in the Atlantic (Haedrich, 1964; Matthews et al., 1977), while trophic ecology of this species in the Indian Ocean is poorly known. A few published data based on small samples are available for the eastern part of the Indian Ocean (Parin et al., 1969; Fujita \& Hattori, 1976), or are focused on the identification and the morphology of cephalopod prey (Okutani $\&$ Tsukada, 1988). The first comparative description of the forage fauna of lancetfish, swordfish and yellowfin tuna in the Seychelles waters were published recently (Potier et al., 2007a).

In this paper, a detailed analysis of the lancetfish food composition is presented for two biogeographic provinces of the western Indian Ocean. Using the lancetfish as a biological sampler, stomach content data were used to analyse the structure of pelagic communities of the intermediate trophic levels in these areas and thus allow discussion on some aspects of the feeding behaviour of this predator.

\section{MATERIAL AND METHODS}

\section{Areas of sampling and general regional oceanography. Samples of lancetfish were collected aboard the R/V SRTM 'Nikolai Reshetnyak' during two research cruises ${ }^{1}$ to the western Indian Ocean. The first cruise was carried out in the western equatorial part adjacent to the exclusive economic zones (EEZs) of Somalia, Kenya, and Seychelles (roughly $1^{\circ}-6^{\circ} \mathrm{S}, 46^{\circ}-52^{\circ} \mathrm{E}$ ) from December 1986 to January 1987 , during the winter monsoon. This}

area lies within the Indian Monsoon Gyres Province (MONS) (Longhurst, 1998). In the second cruise, samples were collected in the northern part of the Mauritius EEZ $\left(8^{\circ} 30^{\prime}-11^{\circ} 00^{\prime} \mathrm{S}, 56^{\circ} 00^{\prime}-60^{\circ} 00^{\prime} \mathrm{E}\right)$ near the Saya-de-Malha Bank and the Agalega Islands in April-June 1987, during the spring intermonsoon period and the beginning of the summer monsoon. This area situated in the Indian South Subtropical Gyre Province (ISSG) (Longhurst, 1998). Hereafter, the two sampled areas (Fig. 1) are referred to as Area 1 and Area 2, whereas provinces are mentioned as MONS and ISSG respectively.

The oceanography and climatology of the western Indian Ocean from about $25^{\circ}$ south to its northern shores is dominated by the seasonally reversing monsoon wind system, which determinates directions and speed both shallow and deep currents (Longhurst, 1998). Area 1 is in the zone of interference of the Somali Current, East African Coast Current and Equatorial Countercurrent (Neiman \& Burkov, 1989; Schott \& McCreary, 2001) and is characterized by a deep upper thermocline (over $70 \mathrm{~m}$ ), an oxygen minimum layer between $150-250 \mathrm{~m}$ and a surface salinity above 35\%o (Gouretski \& Koltermann, 2004; Schlitzer, 2006). Area 2 lies within the northern streams of the westward-flowing South Equatorial Current (SEC) (Neiman \& Burkov, 1989; Schott \& McCreary, 2001), which is the most powerful and persistent current in the tropical Indian Ocean (Hastenrath \& Greischar, 1991; Donguy \& Meyers, 1995). This area is characterised by a shallow thermocline (started at 20-25 m depth), an oxygen minimum layer (at 60-120 m), and low surface salinity (below 35\%o) (Gouretski \& Koltermann, 2004, Schlitzer, 2006). The areas under consideration are separated by the hydrochemical front known as south tropical front (STF), which is a natural border between the MONS and the ISSG (Longhurst, 1998). Waters of both provinces are considered as oligotrophic environments, while productivity of MONS is higher due to the influence of the neighbouring coastal upwelling provinces and open ocean upwelling along the equatorial divergence (Longhurst, 1998). Monsoon seasonality of the

${ }^{1}$ This study was completed while first author worked in the Southern Scientific Research Institute of Marine Fisheries \& Oceanography (YugNIRO), Kerch, Crimea, Ukraine 


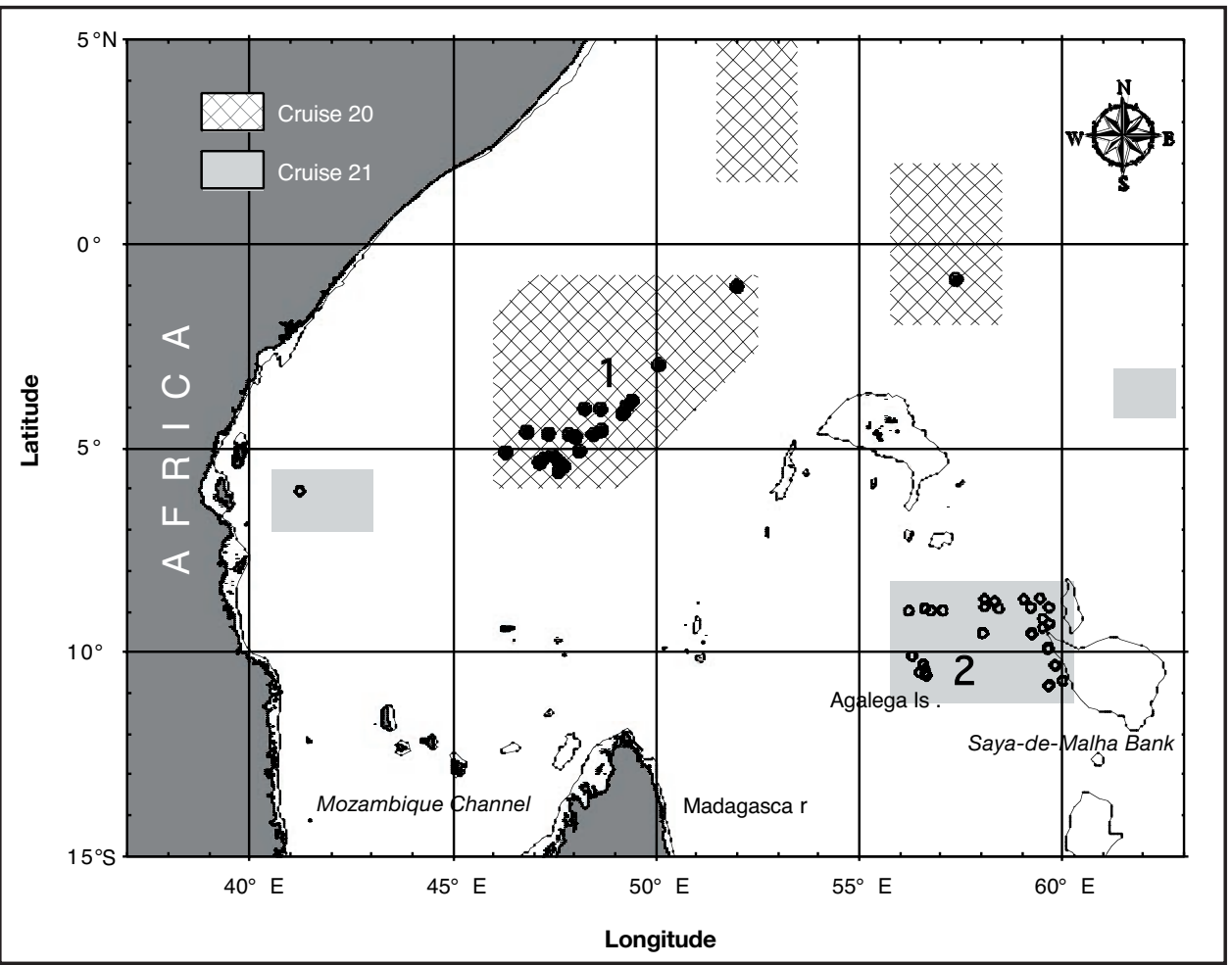

Fig. 1. Sampling areas (shaded) and location of lancetfish caught during the 20th (•) and 21st (0) cruises of R/V SRTM 'Nikolai Reshetnyak'. $200 \mathrm{~m}$ depth isobath is shown. Coastline and bathymetry data are from GEBCO (IOC, IHO \& BODC 2003)

western Indian Ocean introduce strong intraannual variability in the direction and structure of surface currents and productivity of the waters in the MONS whereas water circulation and structure within the ISSG do not reveal great seasonal changes (Longhurst, 1998; Schott \& McCreary, 2001). Differences in the vertical water structure and primary production between the studied areas persist throughout the year (Maksimova, 1989; Neiman \& Burkov, 1989; Longhurst, 1998).

Sampling. The fish were caught with multifilament traditional pelagic tuna longlines deployed in the subsurface waters. The longline hooks were set at and below the thermocline in order to target the temperature niches of yellowfin (Thunnus albacares Bonnaterre, 1788) and bigeye (T. obesus Lowe, 1839) tunas. Temperature $\left({ }^{\circ} \mathrm{C}\right)$, dissolved $\mathrm{O}_{2}\left(\mathrm{~mL} \times \mathrm{L}^{-1}\right)$ and salinity (\%o) profiles were recorded at the beginning and at the end of each longline set, at the beginning and end of hauling, and during the scouting operations. In the Area 1, fishing depths were ranged between 63 and $347 \mathrm{~m}$. Hooks were set shallower in the Area 2 , between 50 and $180 \mathrm{~m}$ (mostly not deeper than $120 \mathrm{~m}$ ). The actual depth of hooks was determined by the length of the baskets ${ }^{2}$, the vessel speed during setting, and the duration of basket shooting. Hook depths were estimated using standard tables (Gerasimov, 1971) although Boggs (1992) and Mizuno et al. (1997, 1998) mentioned differences between estimated and actual hook depths (for monofilament longline gears).

All the lancetfish caught were measured to the nearest $\mathrm{cm}$ (fork length, FL) and weighed to

'Length of the 'basket', i.e. length of the mainline section between two floats was determined by using of one regular basket (300 $\mathrm{m}$ of mainline, 5 hooks between floats) or combining two or three 'regular' baskets into either 'double' (600 m of mainline, 10-11 hooks between floats) or 'triple' (900 m of mainline, 10-11 hooks between floats) basket 
the nearest $10 \mathrm{~g}$. The visual estimates of stomach fullness (using semi-quantitative scale from 0 to $4^{3}$ ) and the weight of stomach contents (to the nearest g) were recorded. All stomachs with food were fixed in 10\% solution of formaldehyde for further detailed analysis in the laboratory.

Data processing and analysis. The stomach contents from 158 lancetfish were analysed, including 52 individuals from Area 1 and 106 individuals from Area 2 (two individuals caught in April in the Area 1 during the $21^{\text {st }}$ cruise of $\mathrm{R} / \mathrm{V}$ Nikolai Reshetnyak (Fig. 1) were pooled with other fish from Area 1). The preliminary field analysis of stomach contents showed considerable differences in the food composition with respect to lancetfish size. In order to further examine this observation, a comparison of stomach contents in each region was made for two size groups, 'small' lancetfish (FL < $100 \mathrm{~cm})$ and 'large' lancetfish $(\mathrm{FL} \geq 100 \mathrm{~cm})$.

The quantitative analysis was based on reconstituted weight (RW) of food items. The RW was estimated using our own relationships between the size of well preserved hard parts of the prey and the length of the prey. Prey length was converted into total weight using length-weight relationships. In many cases, RW was estimated using the relationship between the digestion level of the food item and the weight of the fresh organism, as developed by Fortunatova (1955) for fish, and by Kornilova (1975) for cephalopods and crustaceans.

The Index of Relative Importance (IRI) (Pinkas et al., 1971) was used to assess the integral importance of the different prey of lancetfish:

$$
\mathrm{IRI}=(\mathrm{N}+\mathrm{P}) \times \mathrm{F}
$$

where $\mathbf{N}$ is the numerical percentage, $\mathbf{P}$ is the RW percentage, and $\mathbf{F}$ is the frequency of occurrence of each food item in non-empty stomachs.

To compare the food composition between two size classes of predator or among two areas, the Jaccard Index $\left(\boldsymbol{S}_{J}\right)$ (Bakus, 1990 from Fock, 2000) was used:

$$
S_{J}=\frac{a}{a+b+c}
$$

where $\boldsymbol{a}$ is the number of common prey species; $\boldsymbol{b}$ and $c$ is the number of prey items which occurred only in each size class or in each area. This index varies from 0 (no trophic overlap) to 1 (total similarity).

The foraging intensity of the lancetfish was estimated in the field by the average stomach fullness $\overline{S F}$ and by the Index of Stomach Fullness (ISF):

$$
\overline{S F}=\frac{\sum\left(\mathrm{N}_{i} \times i\right)}{n}
$$

where $\boldsymbol{i}$ is the scale of stomach fullness, $0 \leq \boldsymbol{i} \leq 4 ; \mathrm{N}_{i}$ - number of fish with stomach fullness $\boldsymbol{i} ; \boldsymbol{n}$-sample size, including fish with empty stomachs

$$
\operatorname{ISF}(\%)=\mathrm{SCW} /(\mathrm{TW}-\mathrm{SCW}) \times 100
$$

where SCW is the wet weight of the stomach contents and TW is the total wet weight of the fish. Average values of ISF, calculated for fish with nonempty stomachs, are presented as arithmetic means, with $95 \%$ confidence intervals.

Catches of lancetfish by depth strata are expressed as indexes of relative abundance: 'hook rate' - number of fish per 1,000 hooks.

\section{RESULTS}

Sample size, size frequency, and habitat. The 52 lancetfish (38 non-empty stomachs, $73 \%$ ) caught in Area 1 ranged from 54 to $175 \mathrm{~cm}$ and the 106 lancetfish (68 non-empty stomachs, 64\%) caught in the Area 2 were from 45 to $174 \mathrm{~cm}$ (Fig. 2). Among fish with non-empty stomachs as well in the whole sample, approximately equal numbers of small and large individuals were sampled (Table 1, Fig. 2).

In the Area 1 lancetfish was caught at the estimated depths 87-347 m. Hook rates were the lowest in the subsurface layers $50-99 \mathrm{~m}$ and 100-149 m (0.37 fish and 0.81 fish respectively) and steadily increased from the 150-199 m layer to the 250-299 m layer (from 3.18 to 5.41 fish respectively) (Fig. 3a). Thereafter the hook rate decreased slightly to 4.11 fish at the deepest fished zone (300-349 m). 


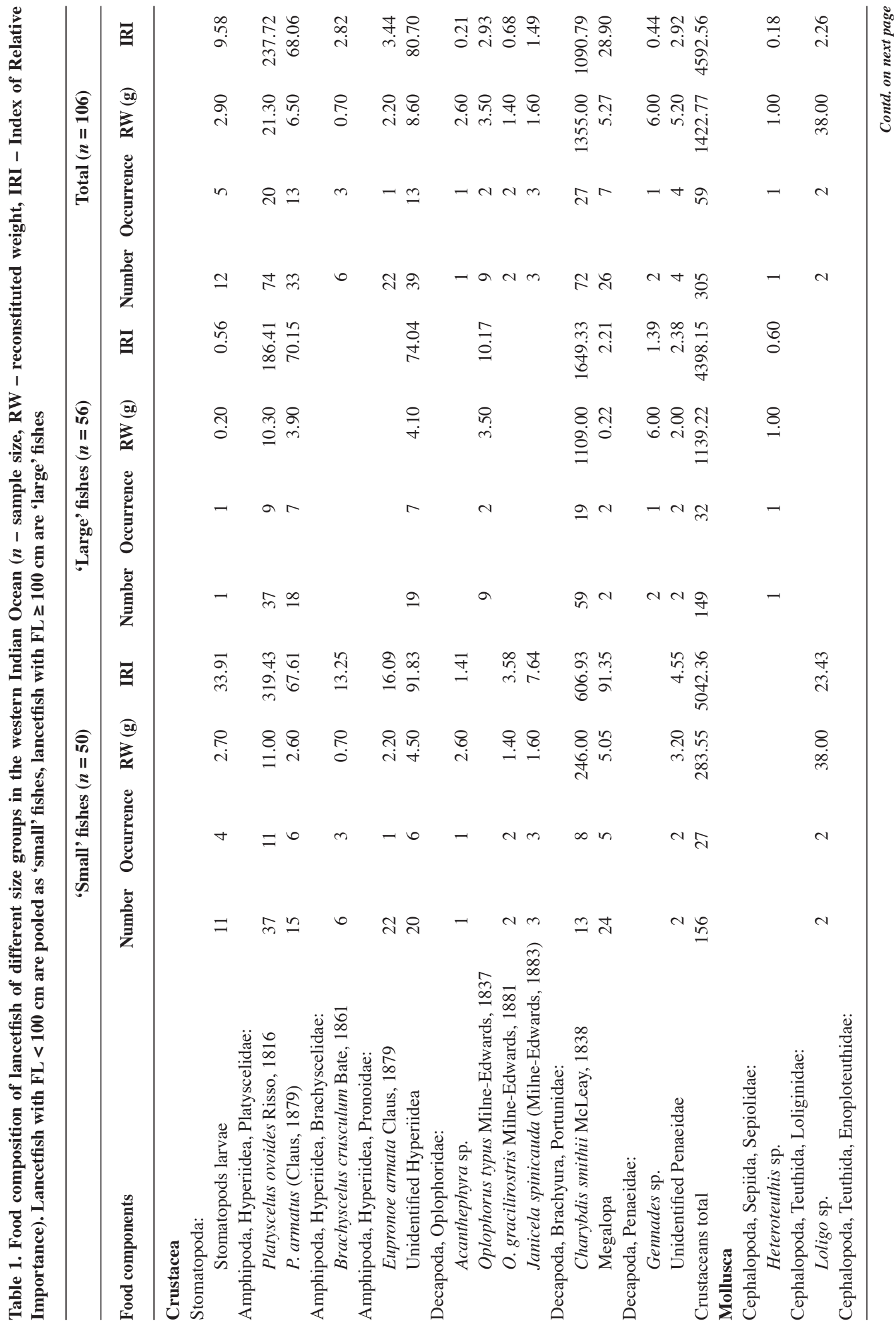




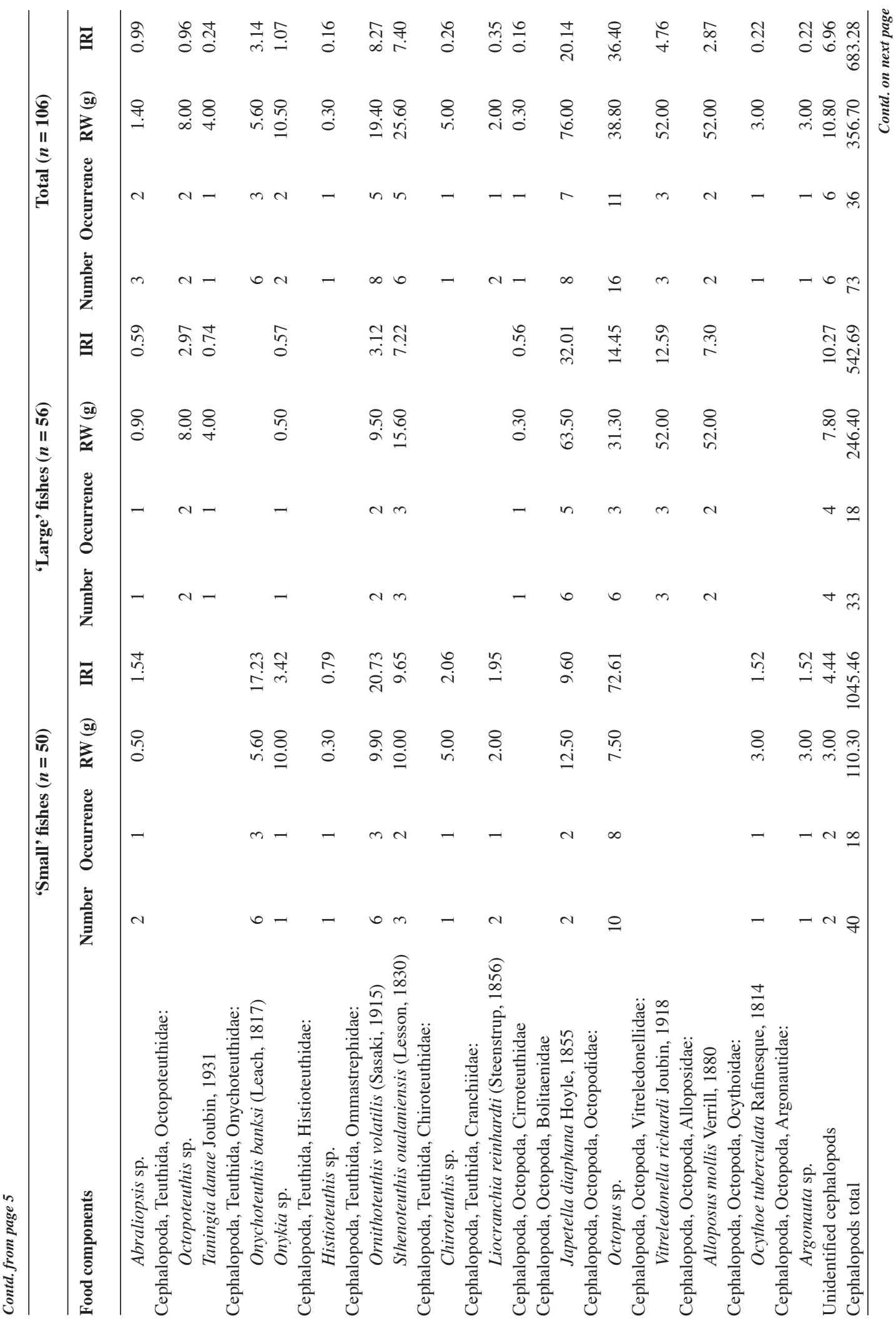




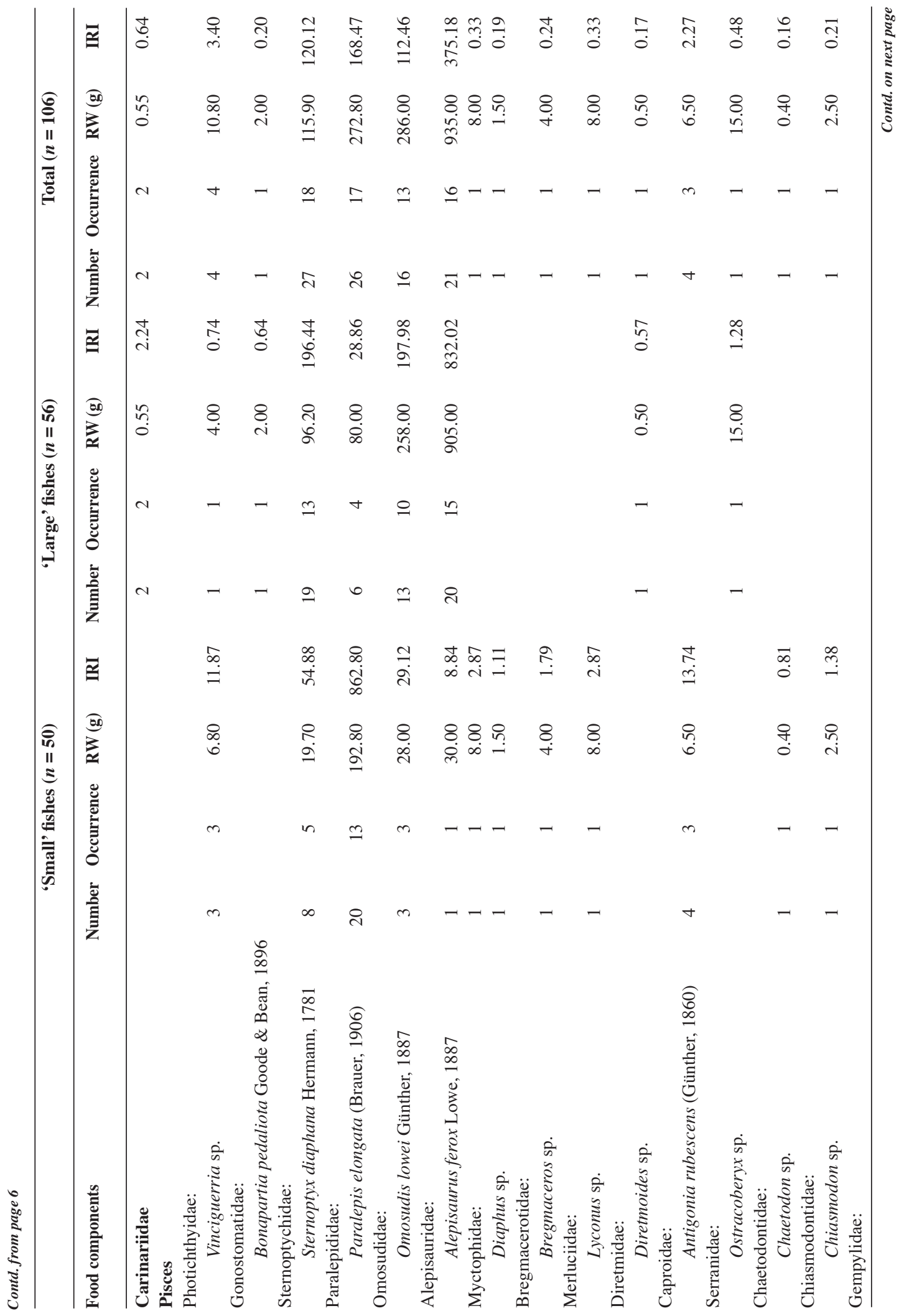









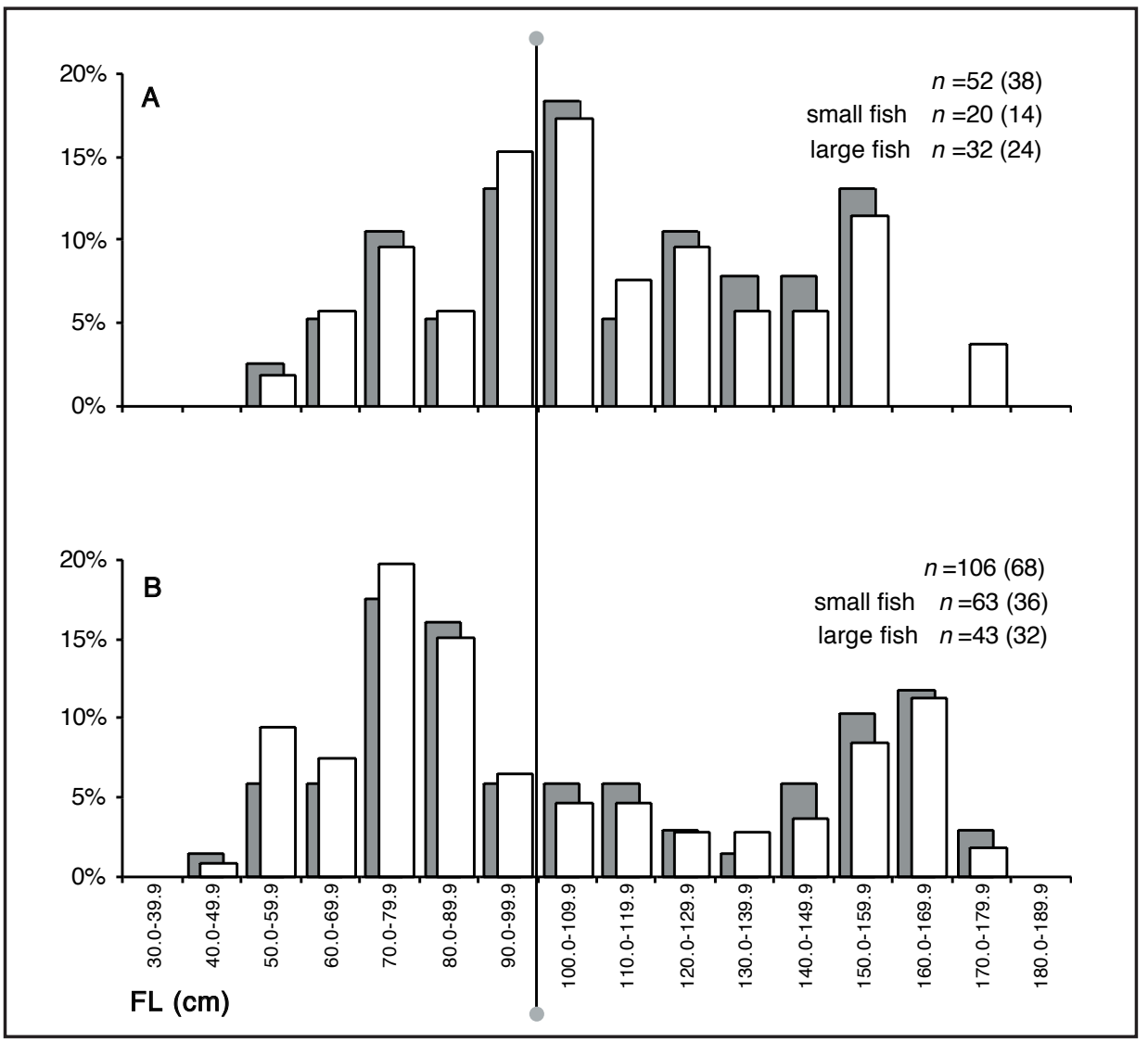

Fig. 2. Size frequency distribution of lancetfish sampled (white columns represents whole sample, grey columns are fish with non-empty stomachs). Black vertical line shows the $100 \mathrm{~cm}$ limit between 'small' and 'large' fishes. A - Area 1, B - Area 2. $n$ is sample size. Figures in brackets are for fish with non-empty stomachs

In the Area 2 lancetfish was caught at the estimated depths 62-120 m. No lancetfish were caught by the deepest hooks (at $151 \mathrm{~m}$ and $171 \mathrm{~m}$ depth). Hook rate in the subsurface layers 50-99 and 100-149 $\mathrm{m}$ were high (8.41 fish and 7.67 fish respectively) (Fig. 3c).

The water temperatures at the depths where lancetfish prevailed were about $11-16^{\circ} \mathrm{C}$ in Area 1 and $14-19^{\circ} \mathrm{C}$ in the Area 2. The dissolved oxygen concentration was $2.6-3.3 \mathrm{~mL} \times \mathrm{L}^{-1}$ and $2.1-2.2$ $\mathrm{mL} \times \mathrm{L}^{-1}$, respectively (Fig. $3 \mathrm{~b}, \mathrm{~d}$ ). Most of the lancetfish were caught in the lower thermocline or directly below it, in the oxygen minimum layer (Fig. 3a, b, c, d).

Food composition. A total of 611 prey items, from 54 families were recorded in the stomachs (Table 1). The highest diversity was recorded for fish prey ( 25 families), followed by cephalopods (14 families), and crustaceans (9 families). Heteropod molluscs (Carinariidae), salps and other tunicates, polychaete worms, and Sargassum algae were also recorded.

Crustaceans and fish were the most important groups, both in terms of IRI (4,592 and 4,022 respectively) and RW (33\% and 58\% of total weight of prey). Cephalopods ranked third but were minor prey (IRI=683) (8\% of total RW) (Table 1$)$. The most important species in the diet of the lancetfish were the swimming (pelagic) crab Charybdis smithii (IRI=1,091) (31\% of total RW), the conspecific individuals $A$. ferox (IRI=375) (21\% of total RW), the hyperiidea Platyscelus ovoides (IRI=238) $(0.5 \%$ of total RW), Polychaeta (IRI=193) $(0.4 \%$ of total RW) the barracudina Paralepis elongata $(I R I=168)(6 \%$ of total RW), the hatchetfish Sternoptyx diaphana (IRI=120) (3\% of total RW), 


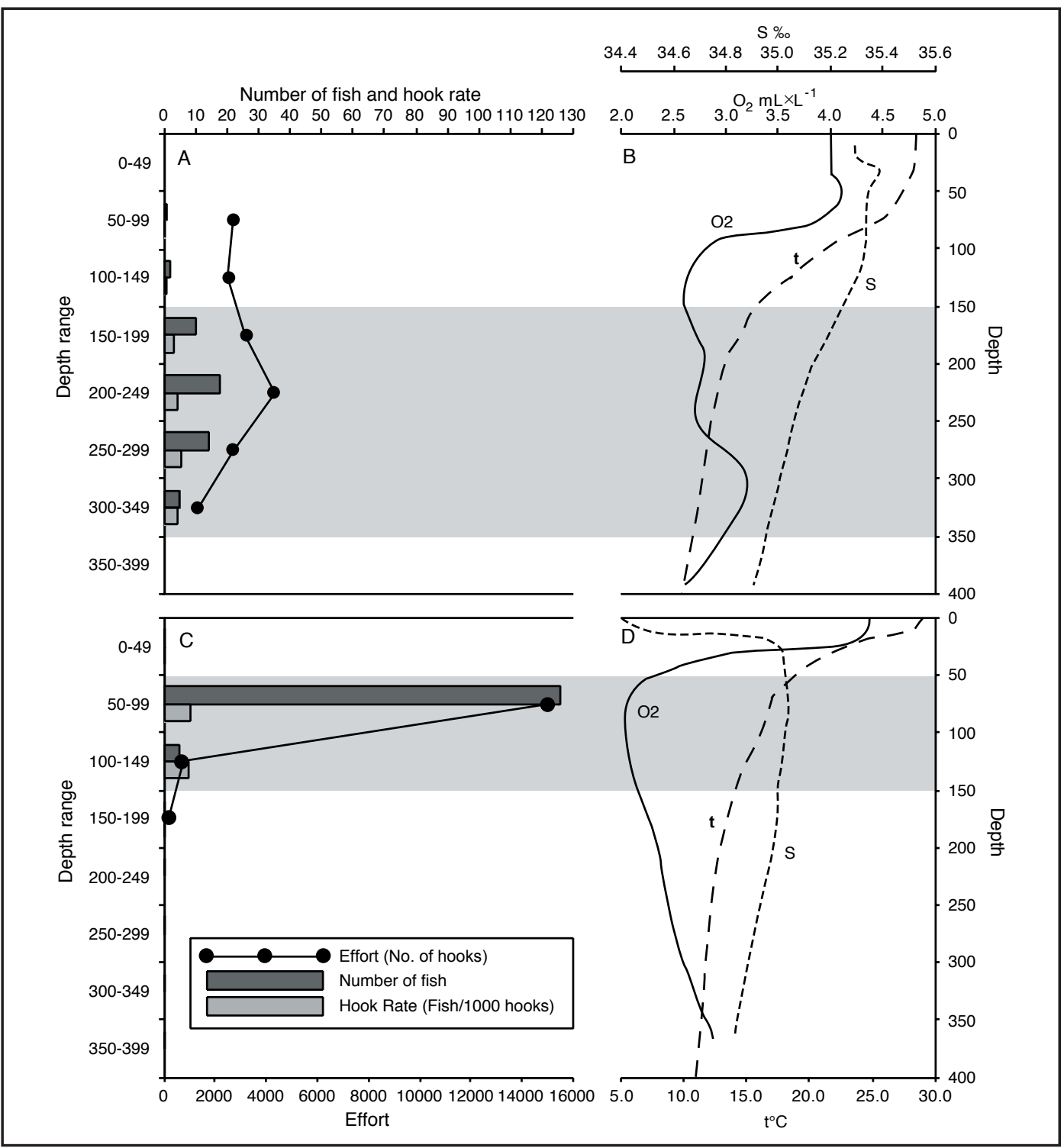

Fig. 3. Vertical distribution of fishing effort (nominal hooks), capture (number of fish) and CPUE (hook rate, fish per 1000 hooks) of the lancetfish in the Area 1 (A), and 2 (C). Typical vertical profiles of the water temperature $\left({ }^{\circ} \mathrm{C}\right)$, dissolved oxygen $\left(\mathrm{mL} \times \mathrm{L}^{-1}\right)$ and salinity $(\%)$ in the respective areas are shown at the panels $B$ and $D$. Shaded area shows depth strata with hook rate higher than 1 fish per 1000 hooks

and hammerjaw Omosudis lowei (IRI=112) (7\% of total RW) (Table 1). Other individual species, including cephalopods (Table 1), were eaten only occasionally ${ }^{4}$ and/or their importance in the diet was low (less than $3 \%$ of IRI and less $2 \%$ of total RW). Those species are not important prey in the studied areas. Reported predation on yellowfin tuna, which gives $18 \%$ of RW also is also not considered here as important for lancetfish population since this record is the only known observation of such interaction (Romanov \& Zamorov, 2002). 
The differences in the food composition of small and large lancetfish observed during preliminary field sampling, was confirmed (Table 1). $S_{J}$ for these two size groups of fish was 0.37 for all prey, 0.50 for crustaceans, 0.32 for molluscs, and 0.35 for fish. These values mean that less than $50 \%$ of the prey items were similar (except for crustaceans where a $50 \%$ overlap was recorded). Principal size-specific differences in food composition were:

1) Large lancetfish had greater rates of cannibalism than small lancetfish. Cannibalism in small lancetfish was recorded only once $(2.0 \%$ in occurrence, $4.0 \%$ in RW). For large lancetfish, the frequency of occurrence of lancetfish in the stomach content was about $25.9 \%$ (21.4\% in RW) for all samples pooled, and up to $45.5 \%$ (40.1\% in RW) in Area 2.

2) Large prey items were recorded in stomachs of large lancetfish, including large specimens of lancetfish, Ostracoberyx sp., Gempylus serpens, Rexea prometheoides, and even fast swimming fishes such as T. albacares (Romanov \& Zamorov, 2002) (Tables 1, 3).

3) Sargassum algae, floating at the surface, was a component of the stomach contents of large lancetfish. The frequency of occurrence of Sargassum increased from $0 \%$ among small lancetfish to $24.1 \%$ among large specimens.

The diet composition of lancetfish varied greatly between the two areas studied. The $S_{J}$ was equal to 0.19 for all prey, 0.21 for crustaceans and molluscs, and 0.15 for fishes. These values indicate a very low similarity in prey species composition between the two areas.

Low diversity of prey species was recorded in the Area 1, with a total of 137 prey specimens from 18 families or higher taxa were found in the stomachs (Table 2). Specimens of 8 families of fishes, 5 families of cephalopods, 4 families of crustaceans, polychaete worms and Sargassum algae were identified. Crustaceans were the main food component (IRI=12,577; $80 \%$ of total RW), while the importance of fishes and cephalopods was considerably lower (IRI $=776,14 \%$ of total RW and IRI $=254,6 \%$ of total RW respectively) (Table 2). The swimming crab, Charybdis smithii, was the predominant prey species by weight and by frequency of occurrence (Table 2). The IRI for this species was 9,398 , which is one order of magnitude higher than that for any other prey species in this area, and weight of crabs constitute $80 \%$ of total RW for all prey. The hyperiids, Platyscelus ovoides, $P$. armatus, and an unidentified hyperiid species, were the second most important food component, but the cumulative IRI for Hypereiidae was only 388; RW was $1 \%$ of total (Table 2). No cannibalism events were recorded in this area.

In the Area 2, a much higher diversity of prey was found, with 474 prey specimens from 54 families or higher taxa recorded in the stomachs (Table 3). The most diverse prey were fishes (23 families), followed by cephalopods (16 families) and crustaceans (9 families). In addition, heteropod molluscs, salpae and other tunicates, polychaete worms, and Sargassum algae were recorded. Fishes (IRI $=6,755,86 \%$ of RW), followed by crustaceans (IRI=1,861, 2\% of RW), and cephalopods (IRI=972, $10 \%$ of RW) were most important components in the diet (Table 3). The prey species composition in Area 2 was diverse, and no single species was dominant in the diet. A high level of cannibalism was recorded. Three species of fish prey prevailed (lancetfish, IRI=929, 35\% of RW; barracudina, IRI $=305,9 \%$ of RW; hatchetfish, IRI $=266$, $4 \%$ of RW) and hyperiids (cumulative IRI for hyperiids $=1,045,1 \%$ of RW). Cannibalism is characteristic for the large lancetfish $(46.9 \%$ occurrence within large fish), while it was recorded only once for small lancetfish $(2.8 \%$ occurrence within small fish).

Foraging success. During the cruises, lancetfish were rarely caught with full stomachs. $27 \%$ of the stomachs in the Area 1 and $36 \%$ in the Area 2 were empty. The $\overline{S F}$ was 1.4 and 1.1 , respectively, i.e. many fish in both areas were caught with empty stomachs or with only traces of food. The average ISF values (computed from non-empty stomachs) were similar in both areas: $2.61 \% \pm 0.61$ and $2.24 \%$ \pm 0.77 (Fig. 4), respectively, i.e. average weight of food was less than $3 \%$ of fish body weight, though the highest ISF value reached was $17.3 \%$.

Since cannibalism was not recorded in the Area 1 , attempts were made to exclude its effect and to compare only diet of lancetfish from the two areas without the conspecific prey. The average weight of non-conspecific prey in the Area 2 was $25.5 \mathrm{~g}$. An unique record of predation on yellowfin tuna (Romanov \& Zamorov, 2002) was also excluded, 
Table 2. Food composition of lancetfish in the Area $1(n=38)$

\begin{tabular}{|c|c|c|c|c|}
\hline Food components & Number & Occurrence & RW (g) & IRI \\
\hline \multicolumn{5}{|l|}{ Crustacea } \\
\hline \multicolumn{5}{|l|}{ Amphipoda, Hyperiidea, Platyscelidae: } \\
\hline Platyscelus ovoides Risso, 1816 & 13 & 6 & 3.70 & 153.26 \\
\hline P. armatus (Claus, 1879) & 9 & 2 & 2.00 & 35.19 \\
\hline Unidentified Hyperiidea & 11 & 3 & 3.00 & 64.78 \\
\hline \multicolumn{5}{|l|}{ Decapoda, Brachyura, Portunidae: } \\
\hline Charybdis smithii McLeay, 1838 & 72 & 27 & 1355.00 & 9398.80 \\
\hline \multicolumn{5}{|l|}{ Decapoda, Penaeidae: } \\
\hline Unidentified Penaeidae & 3 & 3 & 4.00 & 19.15 \\
\hline Crustaceans total & 108 & 30 & 1367.70 & 12576.63 \\
\hline \multicolumn{5}{|l|}{ Mollusca } \\
\hline \multicolumn{5}{|l|}{ Cephalopoda, Teuthida, Loliginidae: } \\
\hline Loligo sp. & 1 & 1 & 15.20 & 4.27 \\
\hline \multicolumn{5}{|l|}{ Cephalopoda, Teuthida, Onychoteuthidae } \\
\hline Onychoteuthis banksi (Leach, 1817) & 1 & 1 & 1.00 & 2.08 \\
\hline \multicolumn{5}{|l|}{ Cephalopoda, Octopoda, Bolitaenidae: } \\
\hline Japetella diaphana Hoyle, 1855 & 4 & 3 & 53.60 & 47.95 \\
\hline \multicolumn{5}{|l|}{ Cephalopoda, Octopoda, Octopodidae } \\
\hline Octopus sp. & 3 & 2 & 24.30 & 19.05 \\
\hline Unidentified cephalopods & 2 & 2 & 3.80 & 8.86 \\
\hline Cephalopods total & 11 & 7 & 97.90 & 254.01 \\
\hline \multicolumn{5}{|l|}{ Pisces } \\
\hline \multicolumn{5}{|l|}{ Paralepididae: } \\
\hline Paralepis elongata (Brauer, 1906) & 4 & 2 & 27.80 & 23.98 \\
\hline \multicolumn{5}{|l|}{ Omosudidae: } \\
\hline Omosudis lowei Günther, 1887 & 5 & 4 & 139.00 & 124.51 \\
\hline Myctophidae & 1 & 1 & 8.00 & 3.16 \\
\hline \multicolumn{5}{|l|}{ Merluciidae: } \\
\hline Lyconus sp. & 1 & 1 & 8.00 & 3.16 \\
\hline \multicolumn{5}{|l|}{ Serranidae: } \\
\hline Ostracoberyx sp. & 1 & 1 & 15.00 & 4.24 \\
\hline \multicolumn{5}{|l|}{ Gempylidae: } \\
\hline Gempylus serpens Cuvier, 1826 & 1 & 1 & 9.00 & 3.31 \\
\hline Diodontidae & 1 & 1 & 20.00 & 5.02 \\
\hline Unidentified fishes & 1 & 1 & 5.00 & 2.70 \\
\hline Fishes total & 15 & 12 & 231.80 & 776.44 \\
\hline Polychaeta & 1 & 1 & 0.20 & 1.95 \\
\hline \multicolumn{5}{|l|}{ Phaeophyta } \\
\hline \multicolumn{5}{|l|}{ Sargassaceae: } \\
\hline Sargassum sp. & 2 & 2 & 2.00 & 8.30 \\
\hline Total & 137 & 38 & 1699.60 & \\
\hline
\end{tabular}

so the average weight of non-conspecific and nonincidental food of lancetfish in Area 2 is was 13.8 g, i.e. 3.2 times lower than in the Area 1 (44.7 g). Average ISF values for non-conspecific/non- incidental prey was also considerably lower than in the Area 1: $1.58 \% \pm 0.55$ (Fig. 4). The nonparametric Mann-Whitney U test shows significant difference between ISF values for Area 1 and ISF 
Table 3. Food composition of lancetfish in the Area $2(n=68)$

\section{Foo
Crustacea
Stomatopoda}

Stomatopoda:

Stomatopods larvae

12

Amphipoda, Hyperiidea, Platyscelidae:

Platyscelus ovoides Risso, 1816

P. armatus (Claus, 1879)

Amphipoda, Hyperiidea, Brachyscelidae:

Brachyscelus crusculum Bate, 1861

Amphipoda, Hyperiidea, Pronoidae:

Eupronoe armata Claus, 1879

Unidentified Hyperiidea

Decapoda, Oplophoridae:

Acanthephyra sp.

Oplophorus typus Milne-Edwards, 1837

O. gracilirostris Milne-Edwards, 1881

Janicela spinicauda (Milne-Edwards, 1883)

Decapoda, Brachyura:

Megalopa

Decapoda, Penaeidae:

Gennades sp.

Unidentified Penaeidae

Crustaceans total

\section{Mollusca}

Cephalopoda, Sepiida, Sepiolidae:

Heteroteuthis sp.

Cephalopoda, Teuthida, Loliginidae:

$$
\text { Loligo sp. }
$$

Cephalopoda, Teuthida, Enoploteuthidae:

Abraliopsis sp.

Cephalopoda, Teuthida, Octopoteuthidae:

Octopoteuthis sp.

Taningia danae Joubin, 1931

Cephalopoda, Teuthida, Onychoteuthidae:

Onychoteuthis banksi (Leach, 1817)

Onykia sp.

Cephalopoda, Teuthida, Histioteuthidae:

Histioteuthis sp.

Cephalopoda, Teuthida, Ommastrephidae:

Ornithoteuthis volatilis (Sasaki, 1915)

Sthenoteuthis oualaniensis (Lesson, 1830)

Cephalopoda, Teuthida, Chiroteuthidae:

Chiroteuthis sp.

6

28

\section{1}

9

2

3

26

\section{2}

1

197

2
1

5

2

1

8

6

1
Occurrence

RW (g)

2.90

19.41

.

(1)

14
11

17.60

4.50

278.55

84.64

5.70

6.95

88.96

5.60

2.60

0.45

3.50

5.97

1.40

1.40

1.60

3.06

5.27

58.50

6.00

0.95

1.20

0.38

55.07

1860.56

29

1.00

0.37

23.00

1.58

1.40

2.02

8.00

2.12

4.00

0.53

4.60

3.61

10.50

2.40

0.30

0.33

19.40

17.76

25.60

16.37

5.00

0.59

Cephalopoda, Teuthida, Cranchiidae:

Liocranchia reinhardti (Steenstrup, 1856)

Cephalopoda, Octopoda, Cirroteuthidae

2

2

Cephalopoda, Octopoda, Bolitaenidae 
Contd. from page 13

Food components
Japetella diaphana Hoyle, 1855
Cephalopoda, Octopoda, Octopodidae
Octopus sp.
Cephalopoda, Octopoda, Vitreledonellidae:
$\quad$ Vitreledonella richardi Joubin, 1918
Cephalopoda, Octopoda, Alloposidae:
$\quad$ Alloposus mollis Verrill, 1880
Cephalopoda, Octopoda, Ocythoidae:
$\quad$ Ocythoe tuberculata Rafinesque, 1814
Cephalopoda, Octopoda, Argonautidae:
$\quad$ Argonauta sp.
Unidentified cephalopods
Cephalopods total
Carinariidae
Pisces

Occ
4

13

3

2

1

$$
1
$$

4

62

2

Photichthyidae:

Vinciguerria sp.

Gonostomatidae:

Bonapartia pedaliota Goode \& Bean, 1896

1

2.00

0.42

Sternoptychidae:

Sternoptyx diaphana Hermann, 1781

Paralepididae:

Paralepis elongata (Brauer, 1906)

Omosudidae:

Omosudis lowei Günther, 1887

Alepisauridae:

Alepisaurus ferox Lowe, 1833

Myctophidae:

\section{Diaphus sp.}

Bregmacerotidae:

Bregmaceros sp.

Diretmidae:

\section{Diretmoides sp.}

Caproidae:

Antigonia rubescens (Günther, 1860)

Chaetodontidae:

$$
\text { Chaetodon sp. }
$$

$$
1
$$

Chiasmodontidae:

Chiasmodon sp.

Gempylidae:

Rexea prometheoides (Bleeker, 1856)

Scombridae:

Thunnus albacares (Bonnaterre, 1788)

Nomeidae:

Cubiceps pauciradiatus Günther, 1872

Citharidae:

Citharoides macrolepis (Gilchrist, 1904)

1 
Contd. from page 14

\begin{tabular}{|c|c|c|c|c|}
\hline Food components & Number & Occurrence & $\mathbf{R W}(\mathbf{g})$ & IRI \\
\hline Pleuronectidae & 1 & 1 & 2.40 & 0.44 \\
\hline \multicolumn{5}{|l|}{ Monacanthidae: } \\
\hline Paramonacanthus barnardi Fraser-Brunner, 1941 & 1 & 1 & 1.50 & 0.39 \\
\hline \multicolumn{5}{|l|}{ Triacanthodidae: } \\
\hline Triacanthodes sp. & 1 & 1 & 0.40 & 0.33 \\
\hline \multicolumn{5}{|l|}{ Ostraciidae: } \\
\hline Lactoria diaphana (Bloch \& Schneider, 1801) & 2 & 2 & 6.30 & 1.94 \\
\hline \multicolumn{5}{|l|}{ Tetraodontidae: } \\
\hline Tylerius spinosissimus (Regan, 1908) & 10 & 4 & 3.50 & 13.18 \\
\hline Diodontidae & 3 & 3 & 9.00 & 4.28 \\
\hline Unidentified fishes & 5 & 3 & 5.50 & 5.56 \\
\hline Fishes total & 122 & 41 & 2300.80 & 6755.41 \\
\hline Unidentified Tunicata & 3 & 2 & 3.40 & 2.24 \\
\hline Salpae & 15 & 5 & 6.00 & 24.92 \\
\hline Polychaeta & 59 & 19 & 17.85 & 366.50 \\
\hline \multicolumn{5}{|l|}{ Phaeophyta } \\
\hline \multicolumn{5}{|l|}{ Sargassaceae: } \\
\hline Sargassum sp. & 13 & 12 & 21.60 & 62.70 \\
\hline Objects of abiotic origin & 1 & 1 & 1.70 & 0.40 \\
\hline Total & 474 & 68 & 2665.97 & \\
\hline
\end{tabular}

values for non-conspecific/non-incidental prey in the Area $2(p<0.0001)$.

\section{DISCUSSION}

Trophic niche. Data obtained during this study has provided evidence that mesopelagic and epipelagic crustaceans and fish were the main prey of lancetfish. Comparison of lancetfish food composition in the western Indian Ocean and in the other oceanic areas (Haedrich, 1964; Haedrich \& Nielson, 1966, Fourmanoir, 1969; Kubota \& Uyeno, 1970; Fujita \& Hattori, 1976; Matthews et al., 1977, Moteki et al., 1993, Tsuchiya et al., 1998) shows that the majority of prey are of the same genera (families): crustaceans (Hyperiidea), fish (Sternoptyx, Alepisaurus, Paralepis, Omosudis) and cephalopods (Onychoteuthis, Heteroteuthis, Loligo, Octopoteuthis, Chiroteuthis, Octopoda, and Argonauta sp.), although there are regional differences in the dominant species. Evidently the trophic niche of lancetfish is similar throughout the world's oceans.

Of note for the western Indian Ocean is the very high importance of the swimming crab C. smithii as a prey of lancetfish in the equatorial waters (Area 1). Recent studies (Potier et al., 2007a, b) show similar high level of lancetfish predation on swimming crab in the neighbouring area (the Seychelles EEZ). Cannibalism is also characteristic for lancetfish (this study, Haedrich, 1964, Fourmanoir, 1969, Matthews et al., 1977, Moteki et al., 1993, Potier et al., 2007a, b).

Feeding habits. Lancetfish is an ambush predator hunting using burst swimming or slow sneaking toward the prey (Romanov \& Zamorov, 2002). Slow swimming species and passive drifters predominate among its stomach content. Large lancetfish however demonstrate higher predation success on evasive prey such as large fish (including conspecifics) and even on fast swimmers (Romanov \& Zamorov, 2002). This is an apparent result of the higher absolute burst swimming speed - relative swimming speed, i.e. body length per second, is slightly decreased with size for angulliform swimming mode (Webb, 1975) - and increased mouth gape of large individuals.

Due to a comparatively large and highly-elastic stomach, lancetfish can swallow incidentally large 


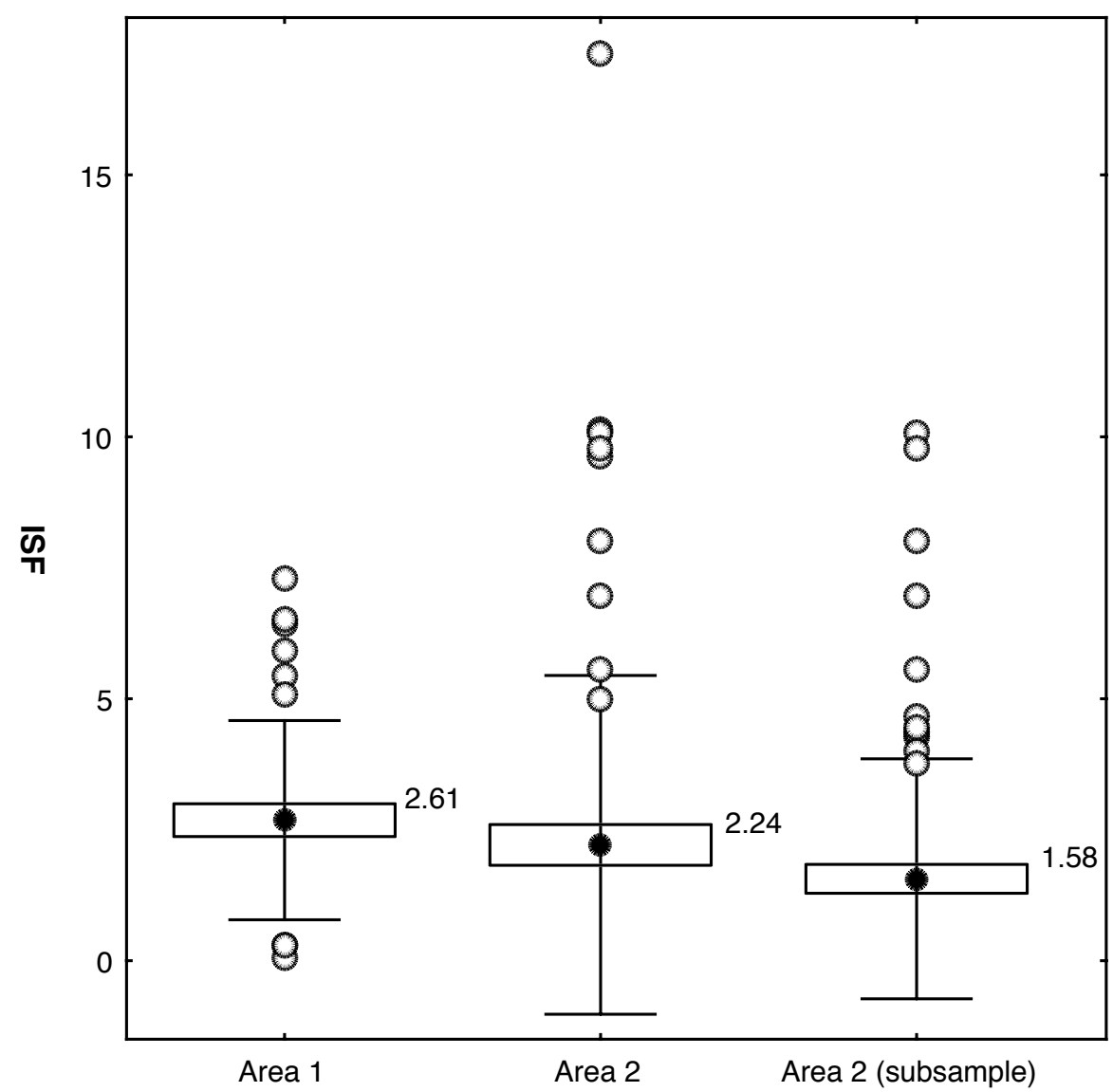

Fig. 4. Variation of the Index of stomach fullness (ISF) of lancetfish in the Area 1 and Area 2. Figure for the Area 2 presents data for whole sample and for sub-sample, which contains non-conspecific and non-incidental prey only (see explanations in the Results section). Dots are means, boxes are standard error, bars are standard deviation, open dots are extreme values

prey (Kubota \& Uyeno, 1970; Fujita \& Hattory, 1976; Romanov \& Zamorov, 2002) or numerous, small fishes, cephalopods, and crustaceans (Parin, 1988). However, according to our observations, lancetfish with full stomachs were rarely recorded. This, and the low degree of food digestion in the stomach, may be an indication of low daily rations. Energy requirements of lancetfish are likely to be low, since ambush predation is more effective and less energetically costly than active chase of prey (Webb, 1984).

Low level of trophic overlap $\left(S_{J} \leq 0.50\right)$ for small and large lancetfish reflects ontogenic shift in the diet toward evasive prey. However, besides conspecifics, the principal prey species in terms of RW are the same for both size groups and expansion of trophic niche with predator size emphasizes the opportunistic nature of lancetfish predation in the oligtrophic pelagic environment. Increase in the absolute prey size with growth of predator is common for marine fish, while trophic niche breadth (i.e. prey size / predator size ratio) is rather stable or even decreased with growth (Scharf et al., 1998, 2000; Ménard et al., 2006). The latter parameter is not discussed here due to accidental loss of primary data on the prey size required for such analysis.

Regional variability. Prevalence of one species in the food of opportunistic feeders reflects its high abundance and/or vulnerability. Lancetfish prey compositions variability in the studied areas is clearly affected by these factors. The narrow diversity of the lancetfish prey in the Area 1 and prevalence of swimming crabs over other prey 
species in the diet of lancetfish (this study) and tuna (Bashmakov et al., 1991) are evidence of high density and availability of crabs in that area.

In the Area 2, the high prey diversity, the low average weight of non-conspecific/non-incidental food of lancetfish (13.3 g), low stomach fullness in terms of $\overline{S F}$ and ISF, and the high degree of cannibalism suggest a low prey density in that area and a higher level of competition for food.

These findings are in conformity with current knowledge on productivity of these areas. The ISSG, which overlapped Area 2 but extends far beyond, is characterised by low-nutrient waters and lowest level of primary production within Indian Ocean (Longhurst, 1998). During our studies in the Area 2, the mixed layer depth varied within 20 and $35 \mathrm{~m}$ (Fig. 3d), which is similar to the long-term norm (Longhurst, 1998). Together with lower salinity waters in the surface layer (below 35\%o) (Fig 3d), characteristic for SEC (Gouretski \& Koltermann, 2004; Schlitzer, 2006) there is have clear indication for the presence of poor SEC waters in this area. Low seasonal variability within the ISSG (Longhurst, 1998; Schott \& McCreary, 2001) also suggests that our observations reflect regional patterns and are not biased by the temporal lag in sampling. The vertical distribution of the lancetfish in the studied areas reveals regional variability in the habitat depth of this predator and its prey. It is unlikely that regional vertical repartition of sampled fish produced any explicit effect on food composition and observed feeding patterns.

Besides variability in the prey abundance between areas within the MONS and the ISSG, our data indicated province-specific differences in the crustacean component of communities of the intermediate trophic levels. High abundance of the pelagic post-larvae stages (juveniles, subadult and even adult individuals) of the large predatory crustaceans of evolutionary benthic origin: $C$. smithii (Kornilova, 1980; Bashmakov et al., 1991; Zamorov et al., 1991a, b; Potier et al., 2004, $2007 \mathrm{a}, \mathrm{b})$ and recently stomatopod Natosquilla investigatoris (Potier et al., 2004, 2007a, b) is characteristic for the MONS. Larvae, non-mature and non-reproductively active individuals of both species are pelagic, while reproduction phase occurs in the benthic environment. Such peculiarity of the life cycle demonstrates relatively recent evolutionary expansion of these species' habitat to pelagic zone. These species is absent in the waters of the ISSG province, where intermediate trophic levels are represented by small pelagic crustaceans. Expansion of originally benthic species outside their native environment is possibly related to the greater availability of food resources in the MONS pelagic realm due to its higher productivity generated by the seasonal monsoon upwelling.

It is recognized that the small sample size (37 non-empty stomachs) in the Area 1 may be source of uncertainty and could affect the results. However, a similar high abundance of swimming crabs were recovered in the stomachs of yellowfin $(n=120)$ and bigeye $(n=56)$ tunas sampled during the same cruise (Bashmakov et al., 1991). These results emphasise that top predators such as lancetfish and tunas are efficient samplers to collect species of intermediary trophic levels which are poorly sampled by conventional gears and whose abundance and distribution are still poorly known in the western Indian Ocean.

Competition for prey with tuna. Comparison of the prey composition of yellowfin and bigeye tuna in the western Indian Ocean (Kornilova, 1980; Bashmakov et al., 1991; Potier et al., 2004, 2007a) and our data for lancetfish showed a high degree of trophic overlap between these species for fish and crustacean prey. Cephalopods are an important prey for tuna but a minor part of the lancetfish diet. Potier et al. (2007a) demonstrate similar results for Seychelles waters.

Although Kornilova (1980) and Potier et al. (2004) found feeding partitioning between yellowfin and bigeye tuna for deep-swimming schools, prey composition of both species in the surface schools was almost identical (Potier et al., 2004). Furthermore, highly similar prey composition for yellowfin and bigeye caught in the deep layers within small-scale spatial-temporal strata (Area 1 in this study) was shown by Bashmakov et al. (1991) and Zamorov (1993). Hence all three species are in competition for the same prey resources although the trophic niche of tunas is broader due to predation on fast swimming species, especially squids (Kornilova, 1980; Bashmakov et al., 1991; Zamorov, 1993; Potier et al., 2007a).

Small lancetfish are a substantial portion of the diet for both tuna species (Kornilova, 1980; 
Bashmakov et al., 1991; Potier et al., 2004, 2007a) while large lancetfish are compete with tuna for the same prey resource. Such relationships suggest a possible control of lancetfish population abundance by tuna through predation and trophic competition.

Further studies are necessary to clarify mechanisms governing local, seasonal and longterm variability in prey abundance and diversity as well as long-term changes in the pelagic ecosystem of the Indian Ocean under natural climate variability and human impact, such as large-scale pelagic fisheries. Probable selectivity in predation by lancetfish, which is usually considered as an opportunistic feeder, should also be addressed to evaluate possible effects of time-area specific foraging behaviour on the estimates of prey abundance in the natural environment based on biological samplers.

Acknowledgments-The authors are grateful to V. A. Spiridonov (MGU) for his help in crustacean identification. Our thanks to M. A. Pinchukov (PINRO), L. K. Pshenichnov, B. G. Trotsenko (YugNIRO) for useful discussions during the preparation of this paper. Thanks to F. Ménard, M. Potier and P. Bach (IRD) for their comments and suggestions to the late versions of the manuscript. Finally we would like to thank two anonymous reviewers for their advice and critical comments, which improved the manuscript and encouraged us to broaden the scope of this paper.

\section{REFERENCES}

Bashmakov, V.F., Zamorov, V.V. \& Romanov, E.V. (1991) Diet composition of tunas caught with long lines and purse seines in the Western Indian Ocean. In: IPTP Coll. Vol. Work. Doc. Vol. 6. Pp. 53-59, TWS/91/31.

Boggs, C.H. (1992) Depth, capture time, and hooked longevity of longline-caught pelagic fish: timing bites of fish with chips. Fish. Bull. 90(4): 642658.

Borodulina, O. D. (1974) Feeding of bigeye tuna Thunnus obesus (Lowe) in Guinea Bay and its place in trophic system of pelagic zone. Vopr. Ikhtiol. 14(5): 881-893 (In Russian).

Borodulina, O. D. (1981) Food composition of the yellowfin tuna Thunnus albacares
(Bonnaterre)(Scombridae) in some habitats. Vopr. Ikhtiol. 21(6): 1006-1015. (In Russian).

Donguy, J. R. \& Meyers, G. (1995) Observation of geostrophic transport variability in the western tropical Indian Ocean. Deep-Sea Res. Part I. 42(6): 1007-1028.

FAO (1995) Code of conduct for responsible fishing. Food and Agriculture Organisation of the United Nations, Rome, FAO. 41pp.

FAO (2003) Report of the Expert Consultation on Ecosystem-based Fisheries Management. Reykjavik, Iceland, 16-19 September 2002. FAO, Rome (Italy). Expert Consult. on Ecosystem-based Fisheries Management, Reykjavik (Iceland), 1619 Sep 2002. FAO Fish. Rep. No. 690, 11pp.

Fock, H. (2000) Analysis of community structure. In: Harris, R.P., Wiebe, P.H., Lenz, J., Skjoldal, H.R., Huntley, M. (Eds.). ICES Zooplankton Methodology Manual. Academic Press. Pp. 154174.

Fortunatova, K.R. (1955) A methodology of studies of predatory fish feeding. 2. Proceedings of the consultation of the Ichthyological Commission. Moscow. Academy of Sciences of the USSR Publishing. Pp. 62-84. (In Russian).

Fourmanoir, P. (1969) Contenus stomacaux d'Alepisaurus (Poissons) dans le Sud-ouest Pacifique. Cah. ORSTOM., ser. Oceanogr. 7(4): 51-60.

Fourmanoir, P. (1971) Liste des espèces de poissons contenus dans les estomacs de thons jaunes, Thunnus albacares (Bonnaterre) 1788 et de thons blancs, Thunnus alalunga (Bonnaterre) 1788. Cah. ORSTOM, ser. Oceanogr. 9(2): 109-118.

Fujita, K. \& Hattori, J. (1976) Stomach content analysis of longnose lancetfish, Alepisaurus ferox in the eastern Indian Ocean and the Coral Sea. Jap. J. Ichthyol. 23(3): 133-142.

Gerasimov, V. G. (1971) Technique and organization in the search of commercial tuna stock in the Indian Ocean from ships of SRTM type. Proc. AzCherNIRO. Kerch. 32: 15-22. (In Russian).

Gouretski, V. V. \& Koltermann, K. P. (2004) WOCE Global hydrographic climatology. A technical report. Berichte des Bundesamtes für Seeschifffahrt und Hydrographie. (35) 52pp.

Grandperrin, R. \& Legand, M. (1970) Contribution à la connaissance d'Alepisaurus dans le Pacifique Equatorial et sud Tropical. Cah. ORSTOM., ser. Oceanogr. 8(3): 11-34.

Haedrich, R. L. (1964) Food habits and young stages on North Atlantic Alepisaurus (Pisces, Iniomi). Breviora. (201): 1-15.

Haedrich, R. L. \& Nielsen, J. G. (1966) Fishes eaten by Alepisaurus (Pisces, Iniomi) in the southeastern 
Pacific Ocean. Deep Sea Research. (13): 909919.

Hastenrath, S. \& Greischar, L. (1991) The monsoonal current regimes of the tropical Indian Ocean: Observed surface flow fields and their geostrophic and wind-driven components. J. Geophys. Res. 96 (C7): 12619-12633

IOC, IHO \& BODC (2003) Centenary Edition of the GEBCO Digital Atlas, published on CD-ROM on behalf of the Intergovernmental Oceanographic Commission and the International Hydrographic Organization as part of the General Bathymetric Chart of the Oceans; British Oceanographic Data Centre, Liverpool.

Kornilova, G. N. (1975) Tuna feeding habits in the northwestern Indian Ocean. Proceedings of VNIRO. Moscow. VNIRO. 108. Pp. 61-68. (In Russian).

Kornilova, G. N. (1979) Trophic chains of predatory fishes from equatorial zone of the Indian Ocean foraging on lancetfishes (fam. Alepisauridae, Pisces). In: Fishery resources of the high seas of the Indian Ocean and their utilization. Moscow. VNIRO. Pp. 81-88. (In Russian).

Kornilova, G. N. (1980) The feeding of the yellowfin tuna Thunnus albacares (Bonnaterre) and bigeye tuna Thunnus obesus (Lowe) in the equatorial zone of the Indian Ocean. Vopr. Ikhtiol. 20(6): 897-905. (In Russian).

Kubota, T. \& Uyeno, T. (1970) Food habits of lancetfish, Alepisaurus ferox (order Myctophiformes) in Suruga Bay, Japan. Japan. J. Ichtyol. 17(1): 22-28.

Longhurst, A. (1998) Ecological geography of the sea. San Diego: Academic Press. 398pp.

Maksimova, M. P. (1989) Biogeneic elements in the waters of the Indian Ocean. In: N. V. Parin \& Novikov N. P. (Eds.). Biological resources of the Indian Ocean. 'Nauka', Moscow. Pp. 66-108. (In Russian).

Matthews, F. D., Damkaer, D. M., Knapp, L. W. \& Collette, B. B. (1977) Food of western North Atlantic tunas (Thunnus) and lancetfishes (Alepisaurus). NOAA Tech. Rep. NMFS SSRF. (706): 1-19.

Ménard, F., Labrune, C., Shin, Y.-J., Asine, A.-S. \& Bard, F.-X. (2006) Opportunistic predation in tuna: a size-based approach. Mar. Ecol. Progr. Ser. 323: 223-231.

Mizuno, K., Okazaki, M. \& Miyabe, N. (1998) Fluctuation of longline shortening rate and its effect on underwater longline shape. Bull. Nat. Res. Inst. Far Seas Fish. (35): 155-164.

Mizuno, K., Okazaki, M., Nakano, H. \& Okamura, H. (1997) Estimation of underwater shape of tuna longline by using micro-BTs. Bull. Nat. Res. Inst. Far Seas Fish. (34): 1-24.

Moteki, M., Fujita K. \& Kohno, H. (1993) Stomach contents of longnose lancetfish, Alepisaurus ferox, in Hawaiian and Central Equatorial Pacific waters. J. Tokyo Univ. Fish. 80(1): 121-137.

Neiman, V. G. \& Burkov, V. A. (1989) Large-scale water circulation in the Indian Ocean. In: N. V. Parin \& Novikov N. P. (Eds.). Biological resources of the Indian Ocean. 'Nauka', Moscow. Pp. 20-66. (In Russian).

Okutani, T. \& Tsukada, S. (1988) Squids eaten by lancetfish and tunas in the tropical Indo-Pacific oceans. J. Tokyo Univ. Fish. 75(1): 1-44.

Parin, N. V. (1968) Ichthyofauna of oceanic epipelagial. Moscow "Nauka", 186pp. (In Russian).

Parin, N. V. (1988) Fishes of the high seas. Moscow, "Nauka", 272pp. (In Russian).

Parin, N. V., Nesis, K. N. \& Vinogradov, M. E. (1969) Feeding of Alepisaurus in the Indian Ocean. Vopr. Ikhtiol. 9(3): 526-538. (In Russian).

Pinkas, L., Oliphant, M. S. \& Iverson, I. L. K. (1971) Food habits of albacore, bluefin tuna and bonito in California waters. Calif. Dept. Fish. Game. Fish. Bull. (152) 105pp.

Potier, M., Marsac, F., Cherel, Y., Lucas, V., Sabatié, R., Maury, O. \& Ménard, F. (2007a) Forage fauna in the diet of three large pelagic fishes (lancetfish, swordfish and yellowfin tuna) in the western equatorial Indian Ocean. Fish. Res. 83: 60-72.

Potier, M., Marsac, F., Lucas, V., Sabatié, R., Hallier, J.-P. \& Ménard, F. (2004) Feeding partitioning among tuna taken in surface and mid-water layers: the case of yellowfin (Thunnus albacares) and bigeye (T. obesus) in the western tropical Indian Ocean. Western Indian Ocean J. Mar. Sci. 3(1): 51-62.

Potier, M., Ménard, F., Cherel, Y., Lorrain, A., Sabatié, R. \& Marsac, F. (2007b) Role of pelagic crustaceans in the diet of the longnose lancetfish Alepisaurus ferox in the Seychelles waters. Afr. J. Mar. Sci. 29(1): 113-122.

Rancurel, P. (1970) Les contenus stomacaux d'Alepisaurus ferox dans le Sud-ouest Pacifique (Céphalopodes). Cah. ORSTOM., ser. Oceanogr. 8(4): 3-87.

Rofen, R. R. (1966) Family Paralepididae. In: Fishes of Western North Atlantic, pt. 5. Mem. Sears Found. Mar. Rep. 5(1): 205-461.

Romanov, E. V. \& Zamorov, V. V. (2002) First record of a yellowfin tuna (Thunnus albacares) from the stomach of a longnose lancetfish (Alepisaurus ferox). Fish. Bull. 100(2): 386-389

Scharf, F. S., Juanes, F. \& Rountree, R. A. (2000) Predator size-prey size relationships of marine 
fish predators: interspecific variation and effects of ontogeny and body size on trophic-niche breadth. Mar. Ecol. Prog. Ser. 208: 229-248.

Scharf, F. S., Juanes, F. \& Sutherland, M. (1998) Inferring ecological relationships from the edges of scatter diagrams: comparison of regression techniques. Ecology. 79: 448-460.

Schlitzer, R. (2006) Ocean Data View, http://odv. awi.de.

Schott, F.A. \& McCreary Jr., J.P. (2001) The monsoon circulation of the Indian Ocean. Prog. Oceanogr. 51: 1-123.

Silas, E. G. (1965) On the lancet fishes of the genus Alepisaurus Lowe from the Indian Ocean. Curr. Sci. 34(2): 51-53.

Silas, E. G., (1969) Exploratory fishing by R/V "Varuna". CMFRI Bull. (12): 1-86.

Tsuchiya, K., Okamoto H. \& Uozumi, Y. (1998) Cephalopods eaten by pelagic fishes in the tropical east Pacific, with special reference to the feeding habit of pelagic fish. Umi. 36(2): 57-66.

Ward, P., Myers, R. A. \& Blanchard, W. (2004) Fish lost at sea: the effect of soak time on pelagic longline catches. Fish. Bull. 102(1): 179-195.
Webb, P. W. (1975) Hydrodynamic and energetics of fish propulsion. Bull. Fish. Res. Board Can. (190) 158pp.

Webb, P. W. (1984) Body form, locomotion and foraging of aquatic vertebrates. Amer. Zool. 24(1): 107-120.

Zamorov, V. V. (1993) (Ms). Feeding and trophic relationships of yellowfin, bigeye tunas and lancetfish in the western Indian Ocean. Ph.D. thesis. Odessa, I. I. Mechnikov Odessa National University. 209pp, 13 annexes. (In Russian).

Zamorov, V. V., Spiridonov, V. A. \& Napadovskii, G. V. (1991a) On the role of swimming crab Charybdis smithii McLeay in the feeding habit of yellowfin tuna Thunnus albacares (Bonnaterre). In: IPTP Coll. Vol. Work. Doc. Vol. 6. Pp. 70-75, TWS/91/33.

Zamorov, V.V.,Spiridonov, V.A.\&Rudnev, G. P. (1991b) On the mass migration to the pelagial and the distribution in the Indian Ocean swimming crab Charybdis smithii McLeay (Crustacea, Portunidae) during pelagic phase of its life-cycle. Zool. Zh. 70(7): 39-42. (In Russian). 